Paideusis

\title{
What Are We Doing when We Are Doing Philosophy of Education?
}

\section{Daniel James Vokey}

Volume 15, Number 1, 2006

URI: https://id.erudit.org/iderudit/1072693ar

DOI: https://doi.org/10.7202/1072693ar

See table of contents

Publisher(s)

Canadian Philosophy of Education Society

ISSN

0838-4517 (print)

1916-0348 (digital)

Explore this journal

Cite this article

Vokey, D. (2006). What Are We Doing when We Are Doing Philosophy of Education? Paideusis, 15(1), 45-55. https://doi.org/10.7202/1072693ar
Article abstract

In this paper I describe a research project designed to address the general question "What are we doing when we are doing philosophy of education?" I also describe how the research results are intended to inform three initiatives: (a) designing philosophy of education courses for Bachelor of Education programs; (b) designing graduate programs in philosophy of education; and (c) maintaining courses and programs in philosophy of education by communicating our relevance to people, academics and otherwise, outside our professional circles. The overall objective of the proposed research is to develop and illustrate a defensible account of the nature and role of philosophy in general and philosophy of education in particular, focusing on the potential role of philosophy of education in promoting consensus on norms and priorities for public education by collaborating in the emergence of a new world view through moral inquiry and discourse. (c) Daniel James Vokey, 2006

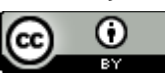

This document is protected by copyright law. Use of the services of Érudit (including reproduction) is subject to its terms and conditions, which can be viewed online.

https://apropos.erudit.org/en/users/policy-on-use/ 


\title{
What Are We Doing when We Are Doing Philosophy of Education?1
}

\author{
DANIEL VOKEY \\ University of British Columbia
}

\begin{abstract}
In this paper I describe a research project designed to address the general question "What are we doing when we are doing philosophy of education?" I also describe how the research results are intended to inform three initiatives: (a) designing philosophy of education courses for Bachelor of Education programs; (b) designing graduate programs in philosophy of education; and (c) maintaining courses and programs in philosophy of education by communicating our relevance to people, academics and otherwise, outside our professional circles. The overall objective of the proposed research is to develop and illustrate a defensible account of the nature and role of philosophy in general and philosophy of education in particular, focusing on the potential role of philosophy of education in promoting consensus on norms and priorities for public education by collaborating in the emergence of a new world view through moral inquiry and discourse.
\end{abstract}

The following research proposal is inspired by the question that Sheryle Dixon chose as a theme for Issue 1 of Volume 15 (now 16) of Paideusis: "How does philosophy of education 'fit' in today's world?" The proposal is still "under construction." My purpose in sharing it at this stage of its development is to invite constructive suggestions on how I might pursue this project either in its present configuration or in some modified form. The project I am proposing is to analyze a representative sample of contemporary Canadian philosophy of education book and journal publications with particular attention to the different kinds of evidence, forms of reasoning, and other means we employ to persuade our readers of the relative merits of our points of view. The general question I hope to answer through the proposed research is - as the title above suggests- "What are we doing when we are doing philosophy of education?" Within the broad scope of this general topic I have identified three categories of more specific questions.

\section{Research Questions}

The first category comprises questions about how our work compares with the ways in which the discipline or field of philosophy of education is characterized in encyclopedia entries, journal articles, and book chapters devoted specifically to that topic. ${ }^{2}$ Examples of this first category of questions

\footnotetext{
1 The question "What are we doing when we are doing Philosophy of Education? is an adaptation of Bernard Lonergan's $(1958,1973)$ approach to epistemology and metaphysics, which was to begin with the question: "What are we doing when we are knowing?"

${ }^{2}$ See, for example, the titles listed in the bibliography.

(C) Copyright 2006. The author, Daniel Vokey, assigns to Paideusis the right of first publication and educational and non-profit institutions a non-exclusive license to use this document for personal use and in courses of instruction provided that the article is used in full and this copyright statement is reproduced. Any other usage is probibited without the express permission of the author.
} 
include: Is there evidence of the existence of competing paradigms of philosophy of education, as Nicholas Burbules (2000, p. 3) and others have suggested? Is there a tension in our work, such as the one described by Maxine Greene (1995; cf. Feinberg, 1995, p. 30), between implicitly or explicitly affirming transcultural standards of rational and moral judgment on the one hand and deconstructing rationality's pretensions on the other? Is there evidence that our social location affects how we do philosophy of education, as Dwight Boyd (1998) and others have maintained?

The second category comprises questions about the ways in which philosophy of education is relevant to educational practice in general and the formation of educational policy in particular. Examples of questions in this second category include: To whom are our publications addressed and with what ends in view? In other words, do we see ourselves as primarily responsible to other philosophers, to educational practitioners, or to some other audience? ${ }^{3}$ Do we attempt to make educational recommendations on the basis of our positions on epistemological or metaphysical issues?

The third category comprises questions about how philosophy of education is to be understood in relation to philosophy in general. Here I would focus on one particular question: "How does what we are doing when we are doing philosophy of education compare with my characterization of the process of moral inquiry as the search for a moral point of view that achieves wide reflective equilibrium?" I will have more to say about this last question below. First, however, I will outline my rationale for the project as a whole in order to provide a context for explaining my particular interest in a comparison between (a) what is going on in philosophy of education and (b) moral inquiry, defined broadly as the search for a satisfactory moral point of view.

\section{Rationale}

My proposal to analyze what we are doing when we are doing philosophy of education is motivated by the following four (related) practical concerns.

1. My first concern is with the design of philosophy of education courses for Bachelor of Education programs. How do we define the topic for student teachers who enroll in philosophy of education courses? What should we encourage them to learn about the history, methodology, and substance of previous work in philosophy of education? What skills of critical analysis and/or creative composition should we help them acquire or refine? Those currently teaching philosophy of education to pre-service teachers in Canada and elsewhere already have their own answers to these questions, and it is no part of my desire to impose homogeneity on the content or process of such instruction. At the same time, I think a description and analysis of contemporary work such as I am proposing would serve as a useful resource to those who design and instruct courses in philosophy of education for Canadian B.Ed programs.

2. My second concern is with the design of graduate programs in philosophy of education. How should we prepare the next generation of philosophers of education to undertake their professional responsibilities? Is there some definable content or method that should be familiar to all who graduate with a philosophy of education masters or doctoral degree? I raise this question because, having observed the changes in the philosophy of education program at OISE/UT between 1987 and 1997, my strong impression is that there is a wide range of not always compatible answers to such questions. Again, while I have no wish to eliminate diversity among or within academic programs in philosophy of education, I expect that a snapshot of the kinds of work in which contemporary philosophers of education are engaged would serve as a useful resource for those involved in graduate program design.

3. My third concern is with maintaining courses and programs in philosophy of education by communicating our relevance to people, academics and otherwise, outside our professional circles. The first two concerns I have

\footnotetext{
${ }^{3}$ See, on this question, the discussion in Burbules (1999).
} 
mentioned presuppose that there will continue to be courses and programs in philosophy of education offered at Canadian universities. However, in some faculties, philosophy of education is either dissolving into integrated/thematic/interdisciplinary courses and programs or simply disappearing. For one example, when the UPEI Faculty of Education introduced a new two-year post-degree B.Ed program in 1998, it dropped the discipline-based courses in History of Education, Sociology of Education, and Philosophy of Education in favour of three thematic, interdisciplinary courses: "Integrated Foundations of Education", "Culture and Society", and "Perspectives on Education". Due to pressure to include more methodology courses, plans to reduce the number of foundations courses by combining the latter two have been discussed for the 2002-2003 academic year.

Concern about a perceived decline in philosophy of education has been expressed at the Annual Meetings of the Canadian Philosophy of Education Society since at least 1994. With regard to the situation in the United States, Donald Arnstine (2002, p. 1) says "Over the past two generations, philosophy of education has suffered a noticeable decline. It does not command a national audience, as John Dewey once did, and it does not exert a significant influence in the education profession. As the numbers of its graduate students and practitioners shrinks, philosophy of education no longer maintains a leading role in teacher education or in graduate education." Assuming there is a decline and that we should be concerned about it, the project I am proposing is intended in part to provide a clearer picture of the different kinds of scholarly activities that we might wish to maintain under the heading "philosophy of education."

Describing what we do is, of course, just the first step. We are unlikely to be successful in maintaining institutional support for philosophy of education courses and programs if their relevance to practical educational issues is not clear. Ivor F. Goodson (1993) expresses a related concern when he claims that

... the old foundational disciplines are no longer politically sustainable and . . f faculties of education will need at long last to collaborate intimately with teachers. The problem is how to maintain a balance between theory, critique, and practical matters. If we cannot strike such a balance I think the main mission and the over-arching rationale for faculties of education will begin to collapse.

I would agree with Burbules (1999) that work in philosophy of education can be both educationally relevant and philosophically sound. Even so, I think that we are still faced with what might be called "the burden of justification" (Burbules, 2000); that is, the task of explaining the value of what we do to those outside our professional circles. The need for communication with broader audiences is a central theme both of the 2001 Report of the Working Group on the Future of the Humanities and of the response to that report from Social Sciences and Humanities Research Council of Canada. ${ }^{4}$ Accordingly, the project I am proposing is intended in part to help us explain and demonstrate why we should be supported in doing what we do when we are doing philosophy of education.

"But how," you may be wondering, "might the proposed project help us justify our continued existence? What might we gain from an analysis of the different kinds of things we undertake in our publications?" My answer has to do with one of the perennial topics of educational debate, which is also the subject of my fourth practical concern.

4. My fourth concern is with promoting wider agreement on norms and priorities for public education. I think it fair to say both that deep-rooted disagreement persists on a wide range of educational issues and that no clear mechanism exists to ensure that policy decisions on those issues are informed by rational public debate. Disputes over what educational and social priorities should inform public school

\footnotetext{
4 "Council endorses the unanimous view expressed at the Humanities in 2010 Conference-and reinforced in the Working Group's Report - that the 'humanities need to find ways of speaking clearly to broad audiences using forms, languages, and media that they can both comprehend and appreciate"' (Response, 2001, p. 1).
} 
curricula appear to be more numerous and ferocious than ever. Given the key role of public education in democratic societies, widespread and fundamental disagreement on norms and priorities for our school systems should be a matter of grave concern. It is with this problem in mind that I am proposing to examine how what we are doing in philosophy of education compares with my characterization of moral inquiry. My goal is to test a hypothesis that my account of what is involved in the search for a satisfactory moral point of view provides a framework that would help us better justify the varied things we do when we are doing philosophy of education as different but potentially complementary ways of promoting wider agreement on norms and priorities for public education.

\section{Theoretical Framework}

The reasoning leading to my hypothesis follows Alasdair MacIntyre's (After Virtue, 1984, esp. pp. 36-39) argument that

* key social and political problems faced by western pluralistic liberal democracies are related in important ways to the inability of the members of such societies to reach rational consensus on moral norms and priorities for public life;

* this inability to reach rational consensus on moral matters is related in important ways to the decline of the role of philosophy is public life;

* the decline of the role of philosophy in public life can be attributed in significant measure to the failure of the Enlightenment project to provide a traditionindependent rational justification for morality; and

* the Enlightenment project failed and, indeed, had to fail because Enlightenment philosophers (a) rejected the teleological world views without which our moral traditions are unintelligible and (b) misunderstood the nature of rational inquiry.

To help restore at least the philosophical conditions for productive public debate on moral issues, MacIntyre has worked to reconstruct and defend a teleological world view and a historicaldialectical conception of rational inquiry that he perceives as internal to the Aristotelian-Thomistic tradition. MacIntyre refers to the historical and dialectical process of rational inquiry as the rationality of traditions. As I understand it, MacIntyre's generic account of the rationality of traditions is intended to chart the middle ground between objectivism and relativism; that is, to explain both (a) how communities of inquiry can validate their constituent agreements in a non-circular and nonfoundational way and (b) how productive argument is possible among people representing rival and incommensurable points of view without recourse to tradition-independent standards of rational justification. ${ }^{5}$ More specifically, MacIntyre reconstruction of Aquinas's teleological ethics is intended to identify the kinds of evidence and argument that distinguish the rationality of moral traditions from other forms of community-based inquiry and practice (Vokey, 2001, pp. 109-171).

\footnotetext{
${ }^{5}$ Bernstein (1983) describes moving beyond objectivism and relativism as a central philosophical problem of the later twentieth century. MacIntyre's account of the rationality of traditions attempts to reject objectivism-the search for the "view from nowhere" or other form of context-free rationality - without falling into the kind of cultural or framework relativism in which rational argument is understood to require reference to standards that cannot themselves be justified and so must be accepted uncritically. It is interesting to note we are faced with a similar problem in formulating a workable account of personal identity. How can we affirm that we are distinct from and so not determined by our socially-constructed identities while also acknowledging that who we are is shaped in important ways by our social location (cf. MacIntyre, After Virtue, pp. 32-33)?
} 
I share MacIntyre's concern about the current marginal status of philosophy in public affairs. The seeming irrelevance of what academic philosophers think or write is described vividly by Ernest Gellner:

If the several thousands or more of professional philosophers in America were all assembled in one place, and a small nuclear device were detonated over it, American society would remain totally unaffected. . . . No one would notice any difference, and there would be no gap, no vacuum, in the intellectual economy, that would require plugging. (Ernest Gellner, "Reflections on philosophy, especially in America" cited in Kekes, 1980, p. 13, note 2.)

Like MacIntyre, I think philosophical inquiry should play a larger role in public life. In particular, I believe philosophy has something important to offer to the informed and careful public debate on the aims and means of public education that should be part of any society aspiring to be genuinely democratic. ${ }^{6}$ And, finally, like MacIntyre, I think a key challenge facing those advocating a more significant role for philosophy in the formation of public policy is to describe how moral conflicts are amenable to rational resolution. I say this because I think one of the greatest challenges facing pluralistic liberal democracies is to create the shared commitment to common values that is required for just and stable democratic societies without compromising individual or group autonomy. And, believing education is fundamentally a moral enterprise, I think the current disagreement on norms and priorities for public education is symptomatic of liberalism's struggle to justify even a thin theory of the good against alternative social and political ideals.

Although I share MacIntyre's concerns, I don't always agree with his epistemology or his ethics. I have found a number of important questions left unanswered within MacIntyre's work, particularly with regard to the kinds of evidence that is central to moral inquiry and argument. Through the process of attempting to address those unanswered questions I have re-characterized the rationality of moral traditions as the search for a moral point of view that achieves wide reflective equilibrium (Vokey, 2001). That search is a complex and multi-faceted process involving many varied kinds of inquiry and varied kinds of practices, philosophical and otherwise. I propose to examine how an account of the different kinds of activities involved in the search for a satisfactory moral point of view compares with a catalogue of the different kinds of things we are doing when we are doing philosophy of education because I expect there will be a significant overlap between the two. If my hunch is correct, then my proposed project would

a) illustrate, support, and (I expect) refine my characterization of moral inquiry, which is intended to defend against the arguments of moral sceptics the potential for rational consensus on moral matters; ${ }^{7}$ and

b) do for philosophy of education something analogous to what Bernard J. F. Lonergan (1973, esp. pp. 125-145) did for theology; that is, identify different "functional specialties" and their potentially complementary relationships.

In other words, I want to see if my characterization of moral inquiry provides a framework for making connections among the various kinds of work we do because I hope doing so would enhance

\footnotetext{
${ }^{6}$ Goodson (1993, p. 3): "In the schools knowledge is transmitted to future generations. If our knowledge of such knowledge transmission is flawed, we are doubly imperilled: schooling is so intimately related to the social order that if either our knowledge of schooling is inadequate or it has no public relevance, then major aspects of social and political life are obscured. In a real way, the future of democracy is any meaningful sense is called into question."

7 This point assumes the validity of my view that philosophy functions to promote agreement on the validity of different forms of knowledge by (a) making explicit what is implicit in successful practice and (b) providing a wider view of knowledge and the world within which that success is intelligible.
} 
philosophy of education's contributions to the overall process of building consensus on the proper norms and priorities for public education.

To summarize, my key assumptions are:

* that the decline in both philosophy and philosophy of education is related to doubts about philosophy's ability to contribute to the resolution of fundamental moral conflict and thus to the building of consensus on norms and priorities for public life;

* that doubts about their relevance is related to an unnecessarily narrow view of philosophical inquiry in general and moral inquiry in particular; and

* that a suitably expanded version of MacIntyre's account of the rationality of moral traditions provides a useful framework both to explain and to enhance philosophy's potential to promote at least some convergence of competing moral points of view.

So far, I have been referring in a very general and abstract way to "the different kinds of activities involved in the search for a satisfactory moral point of view." In my final section, I want to make my proposal a bit more concrete by describing some of the broad categories I would use in my analysis. Those categories would be generated from a combination of my generic account of the process of seeking wide reflective equilibrium (Vokey, 2001, pp. 66-108); my characterization of what the search for wide reflective equilibrium looks like in moral inquiry (2001, pp. 249-282); Lonergan's description of "functional specialties" within theological method cited above; and John D. Crossan's (1975) structural analysis of different functions of narrative.

\section{The Rationality of Traditions as the Search for Wide Reflective Equilibrium}

The first point that I take directly from my reading of MacIntyre is that there is no place from which to advance an argument — or, more generally, to undertake rational inquiry - that is not internal to one or another community of inquiry, understood as the present embodiment of a historical tradition. Communities and corresponding traditions are differentiated by their shared "paradigms" or sets of "constitutive agreements", which include the implicit assumptions, explicit beliefs, attitudes, interests, norms, priorities that are carried in texts, institutions, and practices. Of course, for an initial appreciation of how successful inquiry presupposes shared assumptions and commitments we are indebted to Thomas Kuhn's $(1962,1977)$ work in the philosophy of science.

As I have defined it, the goal of the process of seeking wide reflective equilibrium is to achieve the most overall satisfactory set of agreements in a given context of inquiry and practice, where satisfactory means coherent, mutually-supporting, successful, and defensible. That is to say, wide reflective equilibrium is achieved among a community of inquiry's explicit beliefs, implicit assumptions, attitudes, interests, norms, priorities, and practices when they meet the following four conditions:

1. They are internally-consistent and mutually-supporting.

2. They are consistent with and contribute to the world view and way of life of the larger socio-historical context in which they are embedded.

3. They assist in the accomplishment of the aims and objectives of the members of that community of inquiry.

4. They are defensible in dialectical encounters with competing paradigms of inquiry.

Conversely, equilibrium can be disturbed within a community of inquiry on any of the following four occasions: 
1. There is a perception of internal incoherence among the assumptions and commitments directing their particular form of inquiry.

2. There is a perception of incoherence between those shared agreements and the other beliefs, assumptions, attitudes, interests, norms, priorities, or practices of their broader world view and way of life.

3. Their point of view proves inadequate to fulfilling intentions to which they assign a high priority.

4. There is a perception that the set of assumptions and commitments shared within a competing community of inquiry provides a better means of accomplishing their own fundamental intentions, and a better explanation of their own limitations and failures, than their own framework can provide.

On this account of rational justification, the relative merits of competing points of view are properly assessed by determining which approaches the state of wide reflective equilibrium more closely than its rivals. Thus the choice of one tradition's paradigm of inquiry over others is justified, not by appeal to any single measure of its rational superiority, but by appeal to its overall combination of internal and external coherence, success in furthering its fundamental interests, and ability to account for the limitations of other points of view.

MacIntyre observes that communities and traditions of inquiry are characterized by disagreement as well as consensus. Their conceptual frameworks and other commitments develop through both internal and external debates. For an individual to participate in any form of rational inquiry they must be initiated into the corresponding community and learn to take up its arguments as their own. Consider, for example, what is involved in taking up research and/or practice within the Kohlbergian cognitive-developmental paradigm of moral development and moral education. Some of the tasks involved in furthering that research tradition would include

* Interpreting the conceptual framework: trying to arrive at an accurate formulation of Kohlberg's theory through a close reading of his work and by investigating his intellectual debts to others such as Piaget and Kant;

* Revising and/or extending the theory both (a) to address outstanding issues such as the nature and justification of a final stage of moral development and (b) to integrate relevant developments in other disciplines, e.g., work on relational view of the self or on moral agency;

* Relating the conceptual framework to practice: on the one hand, identifying the kinds of educational initiatives that would promote moral development as conceived within that scheme; on the other, considering what the failures and successes of moral education programs attempting to help individuals reason and act justly imply for the theory; and

* Engaging in dialectical argument with competing traditions such as the Ethics of Care.

One point I wish to underline here is that, in philosophical as in other forms of research, individual studies need to locate their intent and significance within larger projects. A second point is that the search for wide reflective equilibrium only works to the extent that inquiry is not deformed by personal or group bias. To show that the commitments or practices of a tradition and corresponding community of inquiry is compromised by desire for power/domination is an important internal or external critique. A third point is that, because rival and incommensurable points of view represent much more the beliefs that can be objectified in propositional form, the search for wide reflective equilibrium both within and between traditions of inquiry involves a great deal more than argument. For argument or debate to be productive, there must be some common ground among the participants, for arguments appeal to what is already accepted, if only for the sake of argument (Hamlyn, 1970, p. 
50). Every productive debate thus presupposes agreement that cannot be established by its particular form or forms of argument. Much important work in philosophy in general and philosophy of education in particular is concerned with helping us learn to see with new eyes, hear with new ears, and respond with new sensibilities (Bai, 2001). In this connection, among others, historical and fictional stories play important roles, and I expect Crossan's schema will be useful in describing how different forms of narrative contribute to the development of a shared horizon for philosophical discourse.

How does this generic account of wide reflective equilibrium apply to moral inquiry in general and, in particular, to the effort to build consensus among people representing very different moral points of view?

\section{The Search for a Satisfactory Moral Point of View}

Moral point of view is my term for the combination of an overall view of the world, knowledge, and human nature with a set of norms and priorities for human life. I have argued elsewhere that moral points of view take their basic shape from one or another binary opposition, examples of which include: grace and salvation vs. sin and damnation, righteousness vs. unrighteousness, enlightenment vs. ignorance, patriarchy vs. post-patriarchy, capitalism vs. the classless society, technical rationality vs. practical wisdom, "this world" vs. "that world." Here I will simply stipulate that moral points of view incorporate moral values, defined as those things we believe are most worth caring about deeply. On my account, the explicit beliefs, implicit assumptions, attitudes, interests, norms, and priorities of our overall moral perspectives achieve wide reflective equilibrium to the extent they meet the following four conditions:

1. They are internally-consistent and mutually-supporting.

2. They are consistent with the assumptions and commitments of the other, more specific traditions of inquiry and practice in which we are engaged (physics, sociology, literary criticism, medicine, education, and so forth).

3. They yield a way of life that is consonant with our deepest apprehensions of what is more and what is less genuinely worth caring about.

4. They are defensible in dialectical encounters with the points of view of competing moral traditions.

Conversely, we might become dissatisfied with our moral point of view for any of the following reasons:

1. There are contradictions among the assumptions and commitments directing our overall way of life.

2. There are contradictions between those overall assumptions and commitments on the one hand and, on the other, the beliefs, attitudes, interests, norms, and priorities that direct the more specific forms of inquiry and/or practice in which we are engaged.

3. There are conflicts between our way of life and our deepest apprehensions of what is more or less genuinely worth caring about.

4. Our moral point of view proves less adequate to our deepest concerns than an alternative and incommensurable moral perspective, which also reveals the source of the limitations of our own assumptions and commitments.

The search for a satisfactory moral point of view is a complex and multi-faceted process in part because it is so broad in scope. For one thing, because assessing the strengths and limitations of competing moral traditions includes assessing their corresponding world views and overall ways of life, it can draw 
upon the outcomes of all the various more particular forms of inquiry and practice. For another, because moral inquiry is concerned with justifying the values we assign highest priority, its scope encompasses the outcomes of human attempts throughout history to live satisfying and fulfilling lives.

I think moral inquiry must be very broadly defined because I agree with those who argue that we who inhabit dominant and privileged positions in western democracies need a new world view to inform a radically different way of life. Accordingly, I want philosophy to get back into the business of comparing the strengths and limitations of competing world views. ${ }^{8} \mathrm{I}$ also want us to think more about how the different things we do when we are doing philosophy of education-whether we consider ourselves analytic philosophers, neo-Kantians, critical pedagogues, feminist post-structuralists, or as working at the intersection of such categories-could been seen as different ways of promoting sufficient common ground for just and stable democratic societies.

\section{Limitations}

By limiting itself to the published work of contemporary self-identified Canadian philosophers of education, the analysis I propose would overlook much work undertaken under other descriptions that might qualify as philosophical. ${ }^{9}$ Similarly, it would not examine all the other things that philosophers of education do besides write, e.g., teach courses, conduct workshops, design and run programs, advise graduate students, and so on. Even so narrowly defined, work in philosophy of education presents a wide range of material to be analyzed and I see no easy way of deciding what would count as a representative sample. An additional limitation is that the analysis of the material would reflect my own assumptions about and interests in the philosophy of education.

\section{Summary}

The overall objective of the proposed research is to develop and illustrate a defensible and productive account of the nature and role of philosophy in general and philosophy of education in particular, focusing on the potential role of philosophy of education in promoting consensus on norms and priorities for public education by collaborating in the emergence of a new world view through moral inquiry and discourse.

I wish to underline that it is no part of the intent of the proposed research to exclude any individual or their work by claiming that it is not "real" philosophy of education. On the contrary, one objective is to show how the different kinds of work undertaken within the discipline is (at least potentially) complementary, on the hypothesis that the varied projects being undertaken within philosophy of education would be both more beneficial and more visible if they could be located within a larger framework such as the one I have sketched above. Pursuing this hypothesis might yield one way of showing how philosophy of education "fits" in today's world.

\footnotetext{
${ }^{8}$ John Kekes (1980, p. xii) expresses a similar position: "The thesis of this book is that it is the task of philosophy to show how to live well by the construction and rational justification of world views. It is to philosophy that one should look for a coherent system of rational ideals that gives meaning and purpose to life and in accordance with which its problems can be solved."

${ }^{9}$ My working operational definition of a Canadian philosopher of education is anyone who teaches courses in philosophy of education programs at Canadian universities and/or is resident in Canada and publishes works in philosophy of education. I am open to suggestions for revisions to this definition.
} 


\section{References}

Alternative worlds: The humanities in 2010. (March, 2001). Report of the Working Group on the Future of the Humanities. Published by the Social Sciences and Humanities Research Council: http://www.sshrc.ca/web/about/publications/humanities_report_e.pdf.

Bai, Heesoon. (2001). Challenge for education: Learning to value the world intrinsically. Encounter, 14(1), 86-99.

Barrow, Robin. (1994). Philosophy of education: Analytic tradition. In T. Husen and T. Neveille Postlethwaite (Eds.), The international encyclopedia of education (2 ${ }^{\text {nd }}$ ed., pp. 4442-4447). Oxford: Pergamon Press.

Bernstein, Richard J. (1983). Beyond objectivism and relativism: Science, hermeneutics, and praxis. Pennsylvania: University of Pennsylvania Press.

Boyd, Dwight. (1998). The place of locating oneself(ves)/myself(ves) in doing philosophy of education. In S. Laird (Ed.), Philosophy of Education 1997 (pp. 1-19). Urbana-Champaign: Philosophy of Education Society.

Burbules, Nicholas C. (1999). The dilemma of "relevance" in the philosophy of education. In S. Tozer (Ed.), Philosophy of Education 1998 (pp. 187-355). Urbana-Champaign: Philosophy of Education Society.

Burbules, Nicholas C. (2000). Philosophy of education. In B. Moon, M. Ben-Peretz, and S. Brown (Eds.), Routledge international companion to education (pp. 3-18). New York: Routledge. Accessible at http:// faculty.ed.uiuc.edu/burbules/ncb/papers/phed.html.

Chambliss, J. J. (1996). History of philosophy of education. In J. J. Chambliss (Ed.), Philosopby of education: An encyclopedia (pp. 461-472). New York: Garland Publishing.

Crossan, John D. (1975). The dark interval: Towards a theology of story. Niles, IL: Argus Communications.

Ericson, David. (1992). Philosophical issues in education. In M. Alkin (Ed.), Encyclopedia of educational research (pp. 1002-1007). New York: Macmillan.

Feinberg, Walter. (1995). The discourse of the philosophy of education. In W. Kohli (Ed.), Critical conversations in philosophy of education (pp. 24-33). New York: Routledge.

Goodson, Ivor. F. (1993). The devil's bargain: Educational research and the teacher. Educational Policy Analysis Archives, 1(3), http://olam.ed.asu.edu/epaa/v1n3.html.

Greene, Maxine. (1995). What counts as philosophy of education? In W. Kohli (Ed.), Critical conversations in philosophy of education (pp. 3-23). New York: Routledge.

Hamlyn, D. W. (1970). The theory of knowledge. London: MacMillan.

Kekes, John. (1980). The nature of philosophy. Oxford: Basil Blackwell

Kerdeman, Deborah. (2002). Exposure and expertise: Philosophy for teacher education. In S. Rice (Ed.), Philosophy of Education 2001 (pp. 100-103). Urbana-Champaign: Philosophy of Education Society.

Kuhn, Thomas S. (1962). The structure of scientific revolutions. Chicago: University of Chicago Press.

Kuhn, Thomas S. (1977). The essential tension: Selected studies in scientific tradition and change. Chicago: University of Chicago Press.

Lonergan, Bernard J. F. (1958). Insight: A study in human understanding (revised student edition). San Francisco: Harper and Row.

Lonergan, Bernard J. F. (1973). Method in theology (2d ed.) London: Dartman, Longman, and Todd.

Noddings, Nel. (1995). Philosophy of education. Boulder, CO: Westview Press.

Phillips, Dennis C. (1994). Philosophy of education: Historical overview. In T. Husen and T. Neveille Postlethwaite (Eds.), The international encyclopedia of education (2 ${ }^{\text {nd }}$ ed., pp. 4447-4456). Oxford: Pergamon Press.

Report of the Working Group on the Future of the Humanities: A response from the SSHRC Council. (July, 2001). Published by the Social Sciences and Humanities Research Council, Ottawa, Ontario and available on the SSHRC website www.sshrc.ca. 
Smeyers, Paul. (1994). Philosophy of education: Western European perspectives. In T. Husen and T. Neveille Postlethwaite (Eds.), The international encyclopedia of education (2nd ed., pp. 4456-4461). Oxford: Pergamon Press.

Vokey, Daniel. (2001). Barking up the wrong tree: A response to Dennis Cato's "Talking to the animals." Paideusis, 14(2), 66-71.

Vokey, Daniel. (2001). Moral discourse in a pluralistic world. Notre Dame: University of Notre Dame Press.

\begin{abstract}
About the Author
Daniel Vokey M.A. (Carleton), M.Ed. (Queen's), Ph.D. (Toronto). Associate Professor, Department of Educational Studies, UBC, offering courses in Philosophy of Education, Professional Ethics and Educational Leadership, Conceptual Inquiry and Educational Research, and Spirituality and Holistic/Transformative Education. (604)822-2085.daniel.vokey@ubc.ca

My current research interests include east-west perspectives on the development of practical wisdom, focusing on the experiential side of the theory-practice dialectic through which intellectual and moral virtues are cultivated. In my research and teaching I draw not only from my academic background, but also from my professional career in adventure-based experiential education (typified by Outward Bound) and from my study and practice of Shambhala Buddhism.
\end{abstract}

